\title{
MODALITAS TEKS UUD OMNIBUS LAW RUU CIPTA KERJA SUATU KAJIAN LINGUISTIK FUNGSIONAL SISTEMIK
}

\author{
Neni Suryanirmala ${ }^{1}$, Zul Haeri $^{2}$ \\ ${ }^{1}$ Universitas Teknologi Mataram : ayselneni1@ gmail.com \\ 2Universitas Teknologi Mataram : Zulhaeribhs87@gmail.com
}

Artikel Info

Received : 10 Agus 2021

Accepted : 30 Okt 2021

Published : 29 Nov 2021

\begin{abstract}
Hal utama yang dikaji dalam penelitian ini yaitu modalitas teks UUD Omnibus Law suatu kajian Linguistik Fungsional Sistemik (LFS). Kelogisan permasalah yang akan diangkat adalah jenis modalitas dan tingkat keseringan kemunculan modalitas pada teks UUD Omnibus Law untuk mengetahui modalitas (tinggi, menengah, dan rendah) pada tataran polar positif (probabilitas, keseringan, keharusan dan kecendrungan). Metode pengumpulan data dilakukan melalui dokumentasi dan tekhnik catat. Adapun penganalisisan data menggunakan deskripsi, mengurai dan menggambarkan data yang telah dikumpulkan. Modalitas yang dominan digunakan adalah jenis modalitas: modulasi (modulation) yang menggunakan pengungkapan tinggi; wajib, menengah; diharapkan, rendah; boleh, tinggi ditetapkan, menengah mau, dan rendah ingin sebesar 84 atau (77\%) dari 110 klausa yang terdiri 39 modulasi keharusan tinggi; wajib, 2 modulasi keharusan; diharapkan dan 43 modulasi kecenderungan; ditetapkan dalam teks OMNIBUSLAW, jika dibandingkan dengan jenis modalitas modalisasi (modalization ; kemungkinan dan keseringan ditetapkan sebesar 27 atau (25\%) dari 110 klausa yang terdiri dari 24 modalisasi kemungkinan pasti. 1 modalisasi tinggi selalu dan 1 modalisasi menengah biasa dan 1 menengah biasa barangkali.
\end{abstract}

Kata Kunci: Modalitas, Omnibus Law

\section{A. PENDAHULUAN}

Indonesia terdiri atas berbagai suku bangsa dan bahasa. Sejak berdirinya Negara Republik Indonesia dalam sejarah ketatanegaraan bangsa Indonesia. Hal itu sejalan dengan peraturan perundangundangan yang dibuat oleh pemegang kekuasaan, yang menghasilkan suatu produk politik melalui urutan perundang-undangan, yang kemudian kedudukannya diubah menjadi produk hukum, karena telah memenuhi aspirasi seluruh rakyat Indonesia dan telah taat pada suatu aturan, untuk menjadi produk hukum yang disepakati. Merujuk pada aturan dan kebijakan di Indonesia, dari tahun 2014 sampai dengan Oktober tahun 2018, telah terbit 7621 Peratuan menteri, 765 Praturan Presiden, 452 Peraturan Pemerintah, dan 107 Undang- 
undang. Salah satunya adalah undangundang Omnibus Law.

Omnibus Law dalam literature diawali dengan pemahaman secara gramatikal, yakni kata omnibus berasal dari bahasa latin yang berarti "untuk semuanya". Omnibus Law dikutip dari background paper yang dipublikasikan oleh Library Of Parliament tentang omnibus bill. Omnibus Bill sering disandingkan dengan kata Law yang artinya sebuah peraturan. Omnibus Bill dimulai pada tahun 1888 yang diperatikkan oleh House of Commons Procedure and Practice yang mengajukan RUU persetujuan dua perjanjian jalur kereta api yang terpisah. Omnibus bill terkenal di Kanada pada tahun 1986 dan diadaptasi beberapa Negara di asia tengggara seperti di Vietnam. Penggunaan Omnibus Law di Indonesia mirip dengan Negara Filipina yang mewariskan sistem hukum oleh belanda yaitu civil la.

Hukum dan bahasa merupakan penjelasan kehidupan manusia dalam masyarakat, yang merupakan sebagian dari pejelmaan kebudayaan pada suatu tempat dan waktu. Bahasa dan hukum saling berhubungan, saling mempengaruhi, dan merupakan penjelmaan masyarakat dan kebudayaan, yang sebaliknya dipengaruhi baik oleh bahasa maupun hukum. Bahasa sebagai fenomena sosial yang berbentuk tanda, lambang atau kode yang difokuskan secara sosial, sedangkan pengertian bahasa dalam konteks sosial merupakan tempat berkembangnya teks yang menentukan konteks sosial.

Pada hakikatnya bahasa digunakan oleh para penuturnya dalam berinteraksi. Melalui bahasa, seseorang mengutarakan pikiran dan perasaannya kepada orang lain. Tidak ada komunikasi yang sempurna seperti komunikasi melalui bahasa, karena bahasa dapat diwujudkan dalam bentuk lisan (spoken), tulisan (written), dan isyarat (gesture). Oleh karena itu bahasa adalah wahana yang pertama dan utama dalam komunikasi antar manusia.
Manusia mempergunakan bahasa sebagai sarana komunikasi vital dalam hidup ini. Bahasa adalah milik manusia dan menjadi pembeda umat manusia dengan makhuk hidup lainnya di dunia ini. Bahasa itu dinamis selalu berubah-ubah dan berkembang sesuai dengan kemajuan zaman. Bahasa tidak memainkan peranan yang konstan pada situasi-situasi sosial yang berbeda. Peranan dan fungsi bahasa bergantung kepada situasi dan kondisi, dengan kata lain bergantung kepada konteks. Mengacu pada teori LFS bahwa bahasa itu ada tiga yakni fungsi pemaparan, pengalaman, dan pertukaran. Fungsi bahasa tersebut secara langsung membawa tiga makna idensional, makna personal, dan makna tekstual.

Lingustik Fungsional Sistemik memfokuskan kajiannya pada teks atau wacana. Kesatuan bahasa yang lengkap sebenarnya bukanlah kata atau kalimat melainkan wacana. Wacana adalah cabang ilmu linguistik yang dikembangkan untuk menganalisis suatu unit semantik yang membawa kita kepada pemahaman tentang bahasa. Hubungan bahasa atau teks dengan konteks sosial adalah hubungan yang konstrual artinya konteks sosial menentukan dan ditentukan oleh teks. Teks dalam persfektif Lingustik Fungsional Sistemik merupakan produk konteks yang terdiri atas konteks sosial. Makna teks ditentukan oleh konteks dan konteks menentukan teks. Dengan kata lain makna teks tergantung pada konteks.

Modalitas adalah bagian dari makna antarpesona. Makna antarpesona merupakan aksi yang dilakukan pemakai bahasa dalam saling bertukar pengalaman linguistik yang terepresentasikan dalam makna pengalaman dengan kata lain makna antarpesona adalah makna yang mempertukarkan pengalaman. Maksudnya modalitas merujuk kepada area makna yang terletak antara batas positif 'ya' dan batas negatif 'tidak'. (1) Jika suatu proposisi yang berisikan klausa informasi 
maka disebut indikatif (yaitu informasi yang dinyatakan dan ditanyakan) yaitu modalitas yang terletak antara pilihan 'ya' dan 'tidak' seperti mungkin atau paduan 'ya' dan 'tidak' seperti 'kadang-kadang'. (2) Jika suatu proposal yang berisikan klausa barang dan jasa maka disebut imperative yaitu modalitas tersebut yang terdiri atas keharusan yaitu 'diminta' merujuk kepada aksi perintah dan kecendrungan yaitu 'mau' merujuk kepada aksi tawaran. Jadi (1) disebut modalisasi dan (2) disebut modulasi. Adapun rumusan masalah dalam penelitian ini adalah: a) Jenis modalitas apakah yang terdapat dalam naskah UUD Omnibus Law? b) Bagaimanakah tingkat keseringan kemunculan modalitas pada naskah UUD Omnibus Law?

Teori Linguistik Fungsional Sistemik (LFS) yang dikembangkan oleh M.A.K. Halliday, yang dimana teori ini digunakan untuk menganalisis modalitas dalam teks UUD Omnibus Law. LFS mengartikan bahasa adalah sistem arti dan sistem bentuk, ekspresi untuk merealisasikan makna tersebut. Teori ini memiliki dua konsep yaitu; a) bahasa merupakan teks yang berkonstrual (saling menentukan dan saling merujuk) dengan konteks sosial, b) bahasa merupakan fenomena sosial yang terwujud sebagai semiotika sosial. (Halliday: 1994). ). [8]

Semiotika bahasa terjadi dari dua unsur, yakni arti dan ekspresi. Hubungannya adalah hubungan realisasi, yakni arti direalisasikan oleh ekspresi. Namun berbeda dengan semiotik biasa, semiotik sosial bahasa memiliki unsur lain, yaitu bentuk. Dengan demikian, bahasa dalam interaksi sosial terdiri atas tiga unsur; arti, bentuk dan ekspesi. Hubngan ketiga unsur ini dapat dikatakan sebagai arti (semantic atau discourse semantic) direalisasikan kedalam bentuk (lexicogrammar) dan bentuk ini seterusnya dikodekan oleh ekspresi. Dengan kata lain, dalam pandangan LFS bahasa terdiri dari tiga strata, yakni semantik, tata bahasa, dan fonolog/grafologi. Semantic ini direalisasikan oleh tat bahasa, yang selanjunya tata bahasa diekspresikan fonologi kedalam bahasa lisan atau bahasa tulisan. (Halliday dalam Siragih: 2008). sifat hubungan arti dan bentuk adalah ilmiah dengan pengertian hubungan itu dapat dirujuk kepada konteks sosial, sementara hubungan antara arti dan ekspresi adalah arbiter.

Figura bahasa dan konteks sosial diatas, bahasa diartikan sebagai semiotik sosial yang berfungsi didalam konteks sosial atau bahasa fungsional. Tiga pengertian dalam konteks fungsional. Pertama, bahasa terstruktur sesuai dengan kebutuhan manusia akan bahasa. Kedua, fungsi bahasa dalam kehidupan manusia yang mencangkup makna pemaparan, penggambaran, pertukaran dan merangkai penglaman manusia. Ketiga dari pendekatan konsional setiap unit bahasa adalah fungsional terhadap unit yang lebih besar. Dengan demikian, tata bahasa merupakan teori penalaman manusia yang mencakup teori paparan, pertuaran, dan organisasi makna.

Lingistik Fungsional Sistemik berfokus pada kajian teks atau wacana dalam konteks sosial. Teks dibatasi sebagai unit bahasa yang fungsional dalam konteks sosial. (Halliday dalam ) [1]. Bahasa yang fungsional memberikan arti kepada pemakai bahasa. Dengan demikian, teks adalah unit arti atau unit semantik bukan nit tata bahasa. Hal ini berarti teks dapat berupa suatu naskah (buku), paragraph, klausa, frasa, grup atau bunyi yang menajdi kajian dalam Linguistik Fungsional Sistemik adalah arti. Hubungan bahasa dengan konteks sosial adalah hubungan konstrual; artinya konteks sosial menentukan dan ditentukan oleh teks.

Konteks sosial mengacu kepada segala sesuatu yang tertulos atau terucap, yang mendampingi bahasa atau teks dalam 
peristiwa pemakaian bahasa dalam interaksi sosial. Hal seperti ini juga disebut sebagai konteks eksternal. Seperti di uraikan terdahulu konteks sosial ini di bagi kedlam tiga batasan, yaitu konteks situasi, konteks budaya, dan konteks idiologi. [1]. Ketiga konteks ini membentuk strata dengan pengertian strata yang paling dekat ke lebih kongkret dari pada strata yang lebih jauh dari bahasa. Berdasarkan strata kedekatan kepada bahasa, konteks sosial secara berurut mulai dari konteks situasi, budaya dan idiologi. Konteks situasi terdiri dari apa yang dibicarakan, siapa yang berbicara dalam komunikasi yang diinginkan ataupun tidak diinginkan. [1].

Modalitas merupakan pandangan, pertimbangan, atau pendapat pribadi pemakai bahasa terhadap makna pemaparan pengalaman dalam klausa yang disampaikan dalam interaksi mempertukarkan pengalaman, pemakai bahasa mungkin memberi pendapat pribadi terhadap pengalakan yang dipertukarkan. Pandangan ini dapat berupa pertimbangan pribadi, komentar, sikap, pandangan, atau pendapat pribadi terhadap pengalaman yang disampiakan.

\section{B. METODE}

Pendekatan Penelitian ini menggunakan pendekatan Linguistik Fungsional Sistemik, artinya peneliti sebagai penganalisis teks UUD Omnibus Law. Oleh karena itu, penelitian ini tergolong penelitian deskriftif. Penelitian yang menghasilkan data deskriptif kualitatif yang bertujuan membuat deskripsi secara sistematis, factual, akurat mengenai data, sifat-sifat secara ilmiah. [10] Sumber data dalam penelitian ini berupa data tertulis yang merupakan teks UUD Omnibus Law. Metode pengumpulan data yang digunakan dalam penelitian ini adalah metode simak atau teknik sadap penelitian yang menjadi pengamat atau penyimak.Teknik pengumpulan data bersumber dari teks UUD
Omnibus Law kemudian diperiksa yaitu dengan cara sebagai berikut. a) Membaca seluruh teks dengan cermat dan teliti, b) Mengidentifikasi dan mengamati klausa demi klausa yang mengandung modalitas, c) Menganalisi data. Metode dan Teknik Penganalisisan Data. Teknik penganalisisan data dilakukan dengan prosedur sebagai berikut. Alwasilah (2010:11). [13] a) Mengidentifikasi klausa demi klausa yang mengandung modalitas, b) Merancang kolom modalitas, modalisasi dan modulasi.

c) Menyimpulkan hasil tabulasi, d) Mendeskripsikan hasil penelitianTahap Penyususnan Laporan Hasil Penelitian. Pada tahapan ini Peneliti akan mengidentifikasi klausa-klausa yang ada didalam 5 topik yang diambil sebagai keterwakilan data. Setelah itu merancang kolom modalitas dan menyusun hasil tabulasi, yang terakhir peneliti akan mendeskripsikan hasil penelitian. Tahapan terakhir adalah mempublikasikan hasil penelitian pada jurnal yang sudah terakriditasi.

\section{HASIL DAN PEMBAHASAN}

\section{Deskripsi Data Undang-Undang Republik Indonesia Nomor 11 Tentang Cipta Kerja (OMNIBUSLAW)}

Teks omnibus Law adalah teks sebagai metode yang digunakan untuk mengganti atau mencabut ketentuan dalam undangundang atau mengatur ulang beberapa ketentuan dalam undang-undang ke dalam satu undang-undang (tematik). Pasal 3 RUU Cipta Lapangan Pekerjaan dibuat untuk menciptakan lapangan pekerjaan yang seluas-liasnya bagi rakyat Indonesia secara merata. Adapun yang menjadi sampel dalam penelitian ini adalah; 1) Ketenagakerjaan, 2) Kemudahan, Perlindungan, dan Pemberdayaan Koperasi, Usaha Mikro, Kecil, dan Menengah, 3) Kawasan Ekonomi, dan 4) Investasi Pemerintah Pusat dan Kemudahan Proyek Strategi Nasional. 
Berdasarkan data analisis modalitas dalam teks OMNIBUSLAW diatas, dapat dikatakan pandangan ini dapat berupa pertimbangan pribadi, komentar, sikap, pandangan, atau pendapat pribadi terhadap pengalaman yang disampaikan. Modalitas terdiri atas modalisasi, proposisi, modulasi dan proposal. Keduanya terletak antara polar positif 'ya' dan polar negative 'tidak' dari setiap aksi. Selanjutnya modalisasi terdiri atas (1) probobalitas, yakni pilihan antara konsep polar 'ya' atau 'tidak', yakni mungkin dan (2) keseringan, yakni paduan 'ya' dan 'tidak', yang selanjutnya disebut kadang-kadang. Modulasi yang terletak antara melakukan dan tidak melakukan sesuatu, terdiri atas (1) keharusan, yaitu 'diminta' untuk aksi 'perintah' yang lazim diarahkan kepada orang kedua dan disebut juga obligasi dan (2) kecenderungan, yaitu 'mau untuk aksi 'tawaran' yang lazim diarahkan kepada orang pertama dan disebut juga inklinasi.

4.2.1 Modalitas Yang Mendominasi dalam Teks UUD OMNIBUSLAW |

\begin{tabular}{|c|c|c|c|c|c|c|c|c|c|c|c|c|c|c|}
\hline \multicolumn{15}{|c|}{ Modalitas } \\
\hline \multirow{2}{*}{ Jenis Modalitas } & \multicolumn{6}{|c|}{$\begin{array}{c}\text { Modalisasi } \\
\text { (Modalization) }\end{array}$} & \multicolumn{6}{|c|}{$\begin{array}{c}\text { Modulasi } \\
\text { (Modulation) }\end{array}$} & & \\
\hline & \multicolumn{3}{|c|}{$\begin{array}{c}\text { Kemungkinan } \\
\text { (Probability) }\end{array}$} & \multicolumn{3}{|c|}{$\begin{array}{c}\text { Keseringan } \\
\text { (Usuality) }\end{array}$} & \multicolumn{3}{|c|}{$\begin{array}{l}\text { Keharusan } \\
\text { (Obligation) }\end{array}$} & \multicolumn{3}{|c|}{$\begin{array}{l}\text { Kecenderungan } \\
\text { (Inelination) }\end{array}$} & & \\
\hline Nilai (Value) & $\begin{array}{c}\text { T } \\
\text { (High) }\end{array}$ & $\begin{array}{c}\mathrm{M} \\
\text { (Middle) }\end{array}$ & $\begin{array}{c}\mathrm{R} \\
\text { (Low) }\end{array}$ & $\begin{array}{c}\text { T } \\
\text { (High) }\end{array}$ & $\begin{array}{c}\text { M } \\
\text { (Middle) }\end{array}$ & $\begin{array}{c}\mathrm{R} \\
\text { (Low) }\end{array}$ & $\begin{array}{c}\text { T } \\
\text { (High) }\end{array}$ & $\begin{array}{c}\mathrm{M} \\
\text { (Middle) }\end{array}$ & $\begin{array}{c}\mathrm{R} \\
\text { (Low) }\end{array}$ & $\begin{array}{c}\mathrm{T} \\
\text { (High) }\end{array}$ & $\begin{array}{c}\mathrm{M} \\
\text { (Middle) }\end{array}$ & $\begin{array}{c}\mathrm{R} \\
\text { (Low) }\end{array}$ & \begin{tabular}{|l|l|l}
$\mathrm{J}$ \\
$\mathrm{m}$ \\
1
\end{tabular} & $\begin{array}{l}\text { P } \\
\text { r } \\
\text { s }\end{array}$ \\
\hline $\begin{array}{l}\text { Realisasi / } \\
\text { Pengungkapan } \\
\text { Modalitas UUD } \\
\text { OMNIBUSLAW }\end{array}$ & Pasti & Mungkin & Barangkali & Selalu & Biasa & Kadang & Wajib & Diharapkan & Boleh & $\begin{array}{c}\text { Ditetap } \\
\text { kan }\end{array}$ & Mau & Ingin & $\mathrm{h}$ & $\begin{array}{l}\mathrm{n} \\
\%\end{array}$ \\
\hline Teks & 24 & & & 1 & 1 & & 39 & 2 & & 43 & & & 110 & 100 \\
\hline \multirow[t]{2}{*}{$\begin{array}{c}\text { Jumlah } \\
\text { Modalitas }\end{array}$} & 24 & & & 1 & 1 & & 39 & 2 & & 43 & & & 110 & 100 \\
\hline & \multicolumn{6}{|c|}{$\begin{array}{l}\text { Jumlah seluruh realisasi /pegugkapan modalitas yang } \\
\text { digunakan pada teks UUD OMNIBUSLAW } 26 / 110 \text { jumlah } \\
\text { klausa ) } \times 100=24 \%\end{array}$} & \multicolumn{6}{|c|}{$\begin{array}{l}\text { Jumlah seluruh realisasi / pengugkapan modalitas yang } \\
\text { digunakan pada teks UUD OMNIBUSLAW } 84 / 110 \text { jumlah } \\
\text { klausa ) } \text { × } 100=77 \%\end{array}$} & $\begin{array}{l}\text { Acti } \\
\text { Go to }\end{array}$ & $\begin{array}{l}\text { vate } \\
\text { Setti }\end{array}$ \\
\hline
\end{tabular}

Tabel di atas menunjukkan bahwa modalitas yang dominan digunakan adalah jenis modalitas: modulasi (modulation) yang menggunakan pengungkapan tinggi; wajib, menengah; diharapkan, rendah; boleh, tinggi ditetapkan, menengah mau, dan rendah ingin sebesar 84 atau $(77 \%)$ dari 110 klausa yang terdiri 39 modulasi keharusan tinggi; wajib, 2 modulasi keharusan; diharapkan dan 43 modulasi kecenderungan; ditetapkan dalam teks OMNIBUSLAW, jika dibandingkan dengan jenis modalitas modalisasi (modalization) ; kemungkinan dan keseringan ditetapkan sebesar 27 atau (25\%) dari 110 klausa yang terdiri dari 24 modalisasi kemungkinan pasti. 1 modalisasi tinggi selalu dan 1 modalisasi menengah biasa dan 1 menengah biasa barangkali.

Kemunculan modalitas: modulasi: keharusan dan kecenderungan dinyatakan dengan kata, Dalam melaksakana pelayanana penempatan tenaga kerja wajib memenuhi perizinan berusaha, Setiap pemberi kerja yang mempekerjakan tenaga kerja asing wajib memiliki rencana penggunaan tenaga kerja, Pemerintah pusat dan pemerintah daerah wajib menyelenggarakan sistem informasi dan pendataan UMKM yang terintegrasi, Pada ayat (2) wajib digunakan sebagai pertimbangan untuk menentuan kebijakan mengenai UMKM. Penyederhanaan sebagaimana dimaksud pada ayat satu ditetapkan dengan peraturan daerah, Peraturan perundang-undangan yang ditetapan oleh pemerintah pusat sebagai aturan pelaksanaan dalam penyelanggaraan urusan pemerintahan, Pemerintah daerah yang telah ditetapkan dalam undang-undang untuk menjalankan atau membentuk praturan perundangundangan harus dimaknai sebagai pelaksanaan kewenangan presiden. Selain 
itu, modalitas; modalisasi probabilitas dan keseringan dinyatakan dengan kata Peraturan pelaksanaan dari undangundang ini wajib ditetapkan paling lama 3 (tiga) bulan, Peraturan kepala daerah dilaksanakan oleh kementerian atau lembaga, Telah disampaikan 2 (dua) kali berturut-turut dan tetap tidak dilaksanakan oleh kepala daerah, Pada ayat 1 (satu) huruf a dilakukan paling lama 2 tahun terhitung sejak peraturan pemerintah mengenai pelaksanaan, Pejabat pemerintah yang berwenang dapat menerbitkan izin, standar, dispensasi, dan/atau Konsensi dengan berpedoman pada AUPB, Legalasi adalah pernyataan Badan dan/atau Pejabat Pemerintah mengenai keabsahan suatu Salinan surat atau dokumen. Jadi dalam hal ini teks UUD OMNIBUSLAW menggunakan modalitas pengungkapan yang "pasti, selalu, wajib, ditetapkan dalam modalitas; modalisasi; modulasi polar positif artinya sesuatu yang tertuang dalam teks UUD OMNIBUSLAW adalah sesuatu yang pasti, wajib yang telah di tetapkan dalam teks UUD OMNIBUSLAW akan dilaksanakan oleh pemerintah dalam merealisasikan dan melaksanakan teks UUD OMNIBUSLAW yang berkaitan dengan; a) ketenagakerjaan, b) koperasi dan UMKM, c) kawasan ekonomi, d) investasi, e) cipta kerja, f) pengawasan dan pembinaan, g) ketentuan lain. Hal ini dibuktikan dengan munculnya modalitas tinggi sebanyak 106 dari 110 klausa yang telah di ambil sebagai keterwakilan sampel. Selain itu, terdapat modalitas menengah yang muncul sebanyak 1 yang di tandai dengan teks Pertanggung jawaban hukum atas kerugian investasi jika dapat dibuktikan, Dengan mempertimbangkan prinsip kemampuan keuangan Negara dan kesinambungan fiscal. Teks tersebut menunjukkan pertanggung jawaban yang didasari pada hukum yang masuk kedalam keharusan yang diharapkan, karena hal tersebut dalam posisi pasti dan tidak, selain itu, kata mempertimbangkan dalam teks diatas termasuk kedalam modalitas menengah biasa terhadap pelaksanaan yang akan dilakukan dengan mempertimbangkan kemampuan Negara. teks UUD OMNIBUSLAW memberikan segala kepastian, kewajiban, penetapan, mungkin, diharapkan yang berfokus pada penyampaian orang pertama pemerintah pusat sebagai pengendali kepada orang ke dua pemerintah daerah dan orang ketiga orang yang menjalankan UUD tersebut.

Dominasi kemunculan modalitas, yang dimana persentase kemunculan tersebut lebih pada modalitas: modulisasi: probabilitas: tinggi: objektif: eksplisit, karena pemerintah ingin memberikan kepastian yang terbaik kepada pelaksana UUD sebagai wujud Negara melindungi dan bersikap objektif dalam menentukan suatu keputusan.

\section{KESIMPULAN}

Setelah dilakukan proses analisis pada bab IV di atas, dapat disimpulkan melalui modalitas teks UUD OMNIBUSLAW terdapat 4 kemunculan pada modalitas tinggi, yakni 'pasti', 'wajib', ditetapkan, dan selalu dengan jumlah modalitas 106. Selain itu, pada modalitas menengah hanya muncul 4 kali dengan jumlah modalitas 4 sehingga kemunculan modalitas pada teks terjemahan teks UUD OMNIBUSLAW sebanyak 110 butir. Modalitas: modalisasi: probabilitas: tinggi: pasti: objektif: eksplisit. Pada modalitas: modalisasi: probabilitas: keharusan: wajib: objektif: eksplisit sebanyak 3 butir, disusul modalitas: modulasi: probabilitas: keharusan: kecenderungan 84 atau $77 \%$ dan ditetapkan: modalisasi: kemungkinan: keseringan: objektif: eksplisit sebanyak 26 atau $24 \%$.

Hingga dalam modalitas yang ditemukan dalam teks UUD OMNIBUSLAW bahwasanya pemerintah 
akan melaksanakan apa yang menjadi kewajibanya, berdasarkan UUD yang telah di tentukan dan disepakati. Selain itu, pemerintah juga menginginkan hal yang baik atas apa yang telah di buat dalam UUD untuk memajukan a) ketenagakerjaan, b) koperasi dan UMKM, c) kawasan ekonomi, d) investasi, e) cipta kerja, f) pengawasan dan pembinaa, g) ketentuan lain kepada para pemerintah daerah dan pelaku yang lain sebagai orang ke tiga.

\section{DAFTAR PUSTAKA}

Alwi, Hasan. 1992. Modalitas dalam Bahasa Indonesia. Yogyakarta: KANISIUS.

Alisyahbana, S. Takdir. 1974. Bahasa Hukum, Beberapa Sumbangan Fikiran Menuju ke Arah Pembentukan dan Pemakaian Bahasa yang Baik, dalam Symposium Bahasa dan Hukum tahun 1974 di Medan/Prapat, BPHN.

Arikunto, S. 2006. Metodelogi penelitian. Yogyakarta: Bina Aksara.

Azwar, Saifuddin. 2013. Metode Penelitian. Yogyakarta: Pustaka Pelajar.

Brannen, Julia. 2005. Memadu Metode Penelitian Kualitatif \& Kuantitatif. Yogyakarta: Pustaka Pelajar.

Emzir.2012. Metodologi Penelitian Kualitatif Analisis Data. Jakarta: Rajawali Pers.

Ghani, Abdullah. 1994. Pengantar Kompilasi Hukum Islam Dalam Tata Hukum Indonesia. Jakarta: Gema Insani Press.
Hadikusuma, Hilman. 2013. "Bahasa Hukum Indonesia”. Bandung: Alumni.

Halimatussakdiah. 2010. “ Wacana Kepemimpinan: Analisis Fase dan Modalitas Teks Pidato Presiden Susilo Bambang Yudhoyono Berdasarkan Perspektif Linguistik Sistemik Fungsional”. Program Studi Linguistik Pascasarjana Universitas Sumatera Utara.

Halliday, M.A.K. 1985. An Introduction to Functional Grammar. London: Edward Arnold.

Sinar, Silvana, Tengku. 2012. Teori Dan Analisis Wacana Pendekatan Linguistik Sistemik Fungsional. Medan: IKAPI

Thomas, Linda dan Shan Wareing. 2007. Bahasa, Masyarakat, dan Kekuasaan. Diterjemahkan oleh Abdul Syukur Ibrahim dari Judul Language Society and Power. Yogyakarta: Pustaka Pelajar. 